\title{
A Study on College Students' Attitude towards Mobile Banking Services in Dindigul city
}

\author{
Dr. S. Sukumar, Associate Professor in Commerce, Parvathy's Arts and Science College, Dindigul, \\ India.
}

Abstract - M Banking is a service provided by a bank or other financial institution that allows its customers to conduct financial transactions remotely using a mobile device such as a smartphone or tablet. It is available on $24 * 7$ basis. Transactions are depending on the features of the $M$ banking app provided and typically includes obtaining account balance. It provides the following services are mini statements, checking account history, alerts, monitoring of term deposits, access to loan and card statements, funds transfer, paying third parties, status of requests for credit, cheque book and card requests, find ATM location and general information. In recent era the government introduced digitalization concept in India. Ever since the internet has taken over the world. The banking industry has undergone a major work through this internet. The aim of the study is to find the college students attitude towards M - Banking services because they are the doing more banking transactions and always in the internet. Researcher examine the usage of M Banking services which are offered from the banks and find issues faced by the customer and solutions given for the problems identified by the students. The researcher chosen college students as a respondent for this study. The results are presented in this paper with the following analysis such as ranking, factor analysis and Likert analysis to know the level of opinion of the respondents. From this study observed that most of the users using public sector banking services and customers are changing their password through mobile. Infrastructural factor is playing major role in mobile banking services. Without charges customers are not able to enjoy any services from the banker.

Key Words: Mobile Banking, Features, Problems, Operational methods, Technology, Kinds of Transactions.

\section{INTRODUCTION}

M - Commerce people are enjoying various m-services such are M-agriculture, M-education, M-finance, Mshopping and $\mathrm{M}-$ Banking. Mobile banking is a service provided by a bank or other financial institution that allows its customers to conduct financial transactions remotely using a mobile device such as a smartphone or tablet. Unlike the related internet banking it uses software, usually called an app, provided by the financial institution for the purpose. Mobile banking is usually available on a 24-hour basis. Some financial institutions have restrictions on which accounts may be accessed through mobile banking, as well as a limit on the amount that can be transacted. Mobile banking is dependent on the availability of an internet or data connection to the mobile device. It is providing services to their client in various ways such as Mobile banking over wireless application, Mobile banking over SMS and Mobile banking over unstructured supplementary service data. Presently, Mobile Banking is being deployed using mobile applications developed on one of the following four channels. 1. IVR (Interactive Voice Response) 2. SMS (Short Messaging Service) 3. WAP (Wireless Access Protocol) 4. Standalone Mobile Application Clients

\section{STATEMENT OF THE PROBLEM}

Before the internet was so popular for carrying out banking transactions, people had to go the bank, stand in long queues and the wait for their turns even if they only wanted to check their account balance, withdraw cash or deposit money. But now mobile banking has simplified the lives of many people and given them the option to send money, receive money, check account balance, pay bills etc.... using their mobile phone and the best part is that banks offer mobile banking services for free. In recent era banking services are transferred from $\mathrm{E}$ - Commerce to $\mathrm{M}$ Banking. It is having more convenient and inconvenient to the customers. So that researcher made an attempt to analyse opinion among the college students about $\mathrm{M}$ Banking services titled that A study on college students' attitude towards mobile banking services in Dindigul city.

\section{SCOPE OF M-BANKING}

The M Banking scope is identified which would impact of its services or payments for small concerns and organisations. It is depending upon the Smartphone compatibility, acceptance of mobile banking payments, availability of banking services security issues, quality of banking services and customization of banking services. 


\section{OBJECTIVES}

This study plans to study the college students' attitude towards the mobile banking services. To know the origin of $\mathrm{M}$ - Banking

* To study about the services offered by the banker under M Banking

* To know the reason for choosing M - Banking services

* To ascertain the level of satisfaction with mobile banking services

\# To know the student's difficulties in using mobile banking services

\section{METHODOLOGY}

The present study has been basically designed as a 'Descriptive research' with 'survey' as the technique of research and convenient sampling method adopted. A questionnaire was constructed and validated by the researcher for the collection of data. This study is based on both primary and secondary data. The required primary data was collected from the college students by using the questionnaire constructed and validated by the researcher. The secondary data was collected from the published and unpublished records, books, journals, magazines, newspapers, websites and the like.

\section{SAMPLING DESIGN}

The present study is mainly focused on the college students. The researcher has collected 120 samples but 110 sample respondents had adequate information's each based on convenient sampling method. In order to collect the necessary information from the sample respondents, the researcher has conducted questionnaire method in each and every category. The researcher analysed with the following tools such as percentage analysis, ranking, Likert scaling methods, KMO sampling analysis and factor analysis which is influencing the mobile services.

\section{DATA ANALYSIS AND DISCUSSION}

\subsection{AGE}

Age is the major factor which is influencing to decide and usage of $\mathrm{M}$ Banking transactions. The usage and handling methods, number of transactions, experience of transaction differed from one to another. In this study age group is classified into 18 years, 19 years, 20 years and above 21 years. So that the researcher made an attempt to analyze the age group of the respondents and result is given below table no 1.

Table No 1. AGE CLASSIFICATION

\begin{tabular}{|c|c|c|c|c|c|c|c|c|}
\hline \multirow{2}{*}{ Detail } & \multicolumn{2}{|c|}{ Age 18 } & \multicolumn{2}{c|}{ Age 19 } & \multicolumn{2}{c|}{ Age 20 } & \multicolumn{2}{c|}{ Age > 20 } \\
\cline { 2 - 9 } & res & per & res & per & res & per & res & per \\
\hline Age of Students & 17 & 15.5 & 23 & 20.9 & 37 & 33.6 & 33 & 30 \\
\hline
\end{tabular}

The table 1 express that 15.45 percent respondents are under 18 years category, 20.9 percent respondents are falls on 19 years category, 33.6 percent respondents are coming under the 20 years category and 30 percent respondents are above 20 years category.

\subsection{GENDER AND QUALIFICATION}

Gender and Qualification is the factor to analyse the level of awareness about the $\mathrm{M}$ banking activities. In gender, it is categorized male and female. In qualifications, it is classified UG and PG for this study. Gender and qualification are playing vital role in the $\mathrm{M}$ banking operations. The study result is presented in table no. 2 .

\section{TABLE NO 2. QUALIFICATION \& GENDER OF THE} STUDENTS

\begin{tabular}{|l|c|c|c|c|c|c|c|c|}
\hline \multirow{2}{*}{ Detail } & \multicolumn{2}{|c|}{ Age 18 } & \multicolumn{2}{c|}{ Age 19 } & \multicolumn{2}{c|}{ Age 20 } & \multicolumn{2}{c|}{ Age > 20 } \\
\cline { 2 - 9 } & Res & Per & Res & Per & Res & Per & Res & Per \\
\hline Male & 10 & 58.8 & 13 & 56.5 & 19 & 51.3 & 18 & 54.5 \\
\hline Female & 7 & 41.1 & 10 & 43.4 & 18 & 48.6 & 15 & 45.4 \\
\hline Total & $\mathbf{1 7}$ & $\mathbf{1 0 0}$ & $\mathbf{2 3}$ & $\mathbf{1 0 0}$ & $\mathbf{3 7}$ & $\mathbf{1 0 0}$ & $\mathbf{3 3}$ & $\mathbf{1 0 0}$ \\
\hline \multicolumn{8}{|c|}{ QUALIFICATION } \\
\hline UG & 8 & 47.0 & 18 & 78.2 & 22 & 59.4 & 20 & 60.6 \\
\hline PG & 9 & 53 & 5 & 21.7 & 15 & 40.0 & 13 & 39. \\
\hline & $\mathbf{1 7}$ & $\mathbf{1 0 0}$ & $\mathbf{2 3}$ & $\mathbf{1 0 0}$ & $\mathbf{3 7}$ & $\mathbf{1 0 0}$ & $\mathbf{3 3}$ & $\mathbf{1 0 0}$ \\
\hline
\end{tabular}

It is observed from the Table no 2 that 51 percent comes under Male and 49 percent of peoples falls on the female category. 61.8 percent of students are completed UG and 38.2 percent of the respondents completed PG degree.

\subsection{BANKING SECTOR WISE M-BANKING USERS}

$\mathrm{M}$ banking services are offered by the both Private and Public Sector banks. Everybody is giving various kinds of service to their customers and it is also available in their hands. The researcher made an attempt to analyse the $\mathrm{M}$ Banking service users in these kind of banking sectors and results are presented in table 3.

\section{Table No 3. BANKING SECTOR WISE M-BANKING} USERS

\begin{tabular}{|c|c|c|c|c|c|c|c|c|c|}
\hline \multirow{2}{*}{ Detail } & \multirow{2}{*}{ Tot } & \multicolumn{2}{|c|}{ Age 18 } & \multicolumn{2}{c|}{ Age 19 } & \multicolumn{2}{c|}{ Age 20 } & \multicolumn{2}{c|}{ Age > 20 } \\
\cline { 3 - 10 } & & res & per & res & per & res & per & res & per \\
\hline Public & 61 & 13 & 76.5 & 14 & 60.9 & 21 & 56.8 & 13 & 39.4 \\
\hline Private & 49 & 4 & 23.5 & 9 & 39.1 & 16 & 43.2 & 20 & 60.6 \\
\hline & & $\mathbf{1 7}$ & $\mathbf{1 0 0}$ & $\mathbf{2 3}$ & $\mathbf{1 0 0}$ & $\mathbf{3 7}$ & $\mathbf{1 0 0}$ & $\mathbf{3 3}$ & $\mathbf{1 0 0}$ \\
\hline
\end{tabular}

It is evident from the table no 3 express that majority of the respondents doing their banking transactions through public sector banks. 20 years age category of respondents highly using public sectors bank mobile services. 49 percent of the respondents are availing private sector banking service which given be them through the mobile. Above 20 years age category highly using private sector mobile banking services.

\subsection{DURATION OF USING M-BANKING}

Duration is important in using banking services because based on usage, their knowledge and operation method will be very easy, develop the services by the banker and rectify the problems easily while doing mobile banking transactions. So that the researcher analyse the duration of 
using $\mathrm{M}-$ Banking services and it is classified into three types less than 1 Year, $1-3$ Years, more than 3 Years. The result is presented table no 4 .

\section{TABLE NO 4. DURATION OF USING M BANKING}

\begin{tabular}{|l|c|c|c|c|c|c|c|c|c|}
\hline \multirow{2}{*}{ Detail } & \multirow{2}{*}{ Tot } & \multicolumn{2}{|c|}{ Age 18 } & \multicolumn{2}{c|}{ Age 19 } & \multicolumn{2}{c|}{ Age 20 } & \multicolumn{2}{c|}{ Age > 20 } \\
\cline { 3 - 10 } & & res & per & res & per & res & per & res & per \\
\hline < 1 year & 33 & 6 & 35.3 & 16 & 69.6 & 7 & 18.9 & 4 & 12.1 \\
\hline 1 to 3yrs & 29 & 8 & 47.1 & 5 & 21.7 & 10 & 27 & 6 & 18.2 \\
\hline > 3 years & 48 & 3 & 17.6 & 2 & 8.7 & 20 & 54.1 & 23 & 69.7 \\
\hline & & $\mathbf{1 7}$ & $\mathbf{1 0 0}$ & $\mathbf{2 3}$ & $\mathbf{1 0 0}$ & $\mathbf{3 7}$ & $\mathbf{1 0 0}$ & $\mathbf{3 3}$ & $\mathbf{1 0 0}$ \\
\hline
\end{tabular}

It is learnt from the above table 4 that 30 percent of students are using the M-Banking services a year. 26.36 percent of students are using $\mathrm{M}$ banking service between 1 year to 3 years and 43.64 percent of students are using more than 3 years. Highest duration users had clear view idea about the mobile banking services and they are very familiar to do banking transactions.

\subsection{KINDS OF M - BANKING TRANSACTIONS}

Banker is simplifying and reduce the que in bank for doing their financial transaction. It has done through net banking, UPI payment, Wallet, card system and mobile. The bankers are giving the following facilities to their customer through $\mathrm{M}$ banking such as Account information, Deposit, Bills payment, change password, shopping, investment, fund transfer, card transactions, service request, view account balance, availing offers, booking tickets and transaction history. Table no 5 is presenting a result of kinds of transactions.

\section{Table No 5. KINDS OF M - BANKING TRANSACTIONS}

\begin{tabular}{|l|c|c|c|c|c|c|}
\hline \multirow{2}{*}{ Particulars } & Age 18 & Age 19 & Age 20 & Age > 20 & \multicolumn{2}{c|}{ Total } \\
\cline { 2 - 7 } & Res & Res & Res & Res & Res & Rank \\
\hline A/c Info & 12 & 20 & 25 & 30 & $\mathbf{8 7}$ & VIII \\
\hline Deposit & 15 & 15 & 24 & 12 & $\mathbf{6 6}$ & XI \\
\hline Bills Payment & 16 & 21 & 35 & 27 & $\mathbf{1 0 1}$ & V \\
\hline Change Password & 17 & 23 & 37 & 30 & $\mathbf{1 0 7}$ & I \\
\hline Shopping & 14 & 20 & 32 & 24 & $\mathbf{1 0 0}$ & VI \\
\hline Investment & 6 & 11 & 19 & 10 & $\mathbf{4 6}$ & XII \\
\hline Fund Transfer & 11 & 22 & 30 & 29 & $\mathbf{9 2}$ & VII \\
\hline Card Transaction & 13 & 15 & 28 & 25 & $\mathbf{8 1}$ & X \\
\hline Service Request & 12 & 17 & 32 & 21 & $\mathbf{8 2}$ & IX \\
\hline Viewing Balance & 17 & 21 & 35 & 30 & $\mathbf{1 0 3}$ & III \\
\hline Availing Offers & 8 & 11 & 11 & 12 & $\mathbf{4 2}$ & XIII \\
\hline Booking Tickets & 15 & 22 & 34 & 31 & $\mathbf{1 0 2}$ & IV \\
\hline Transaction History & 16 & 22 & 36 & 31 & $\mathbf{1 0 5}$ & II \\
\hline
\end{tabular}

It is observed from the above table no 5 that Majority of the respondents change their mobile banking password through only mobile. This feature is secured first rank. The second rank secured by Transaction history. Third place goes to Viewing account balance. Fourth rank obtained by the booking Tickets through $\mathrm{M}$ banking. Fifth place secured by the activity Bill payment. Sixth rank secured by shopping in Mobile banking. Other features are used by the minimized respondents.

\subsection{PROBLEMS OF USING M-BANKING}

Day by day technology is inculcated in all the sector. Banking sector converted from manual to machine operations. While implementing technology the banking sector had more problems that are handset operability, security, high charges, unreliability, inaccessibility, no awareness, mother of operations, not user friendly and nonupdating of transactions. The researcher analysed the above said problems and presented results in table 6.

Table No 6. PROBLEMS OF USING M - BANKING

\begin{tabular}{|l|c|c|c|c|c|c|}
\hline \multirow{3}{*}{ Particulars } & $\begin{array}{c}\text { Age } \\
\mathbf{1 8}\end{array}$ & $\begin{array}{c}\text { Age } \\
\mathbf{1 9}\end{array}$ & $\begin{array}{c}\text { Age } \\
\mathbf{2 0}\end{array}$ & $\begin{array}{c}\text { Age> } \\
\mathbf{2 0}\end{array}$ & \multicolumn{2}{c|}{ Total } \\
\cline { 2 - 8 } & Res & Res & Res & Res & $\begin{array}{c}\text { Re } \\
\text { s }\end{array}$ & $\begin{array}{c}\text { Ran } \\
\text { k }\end{array}$ \\
\hline Handset Operability & 17 & 23 & 37 & 33 & $\begin{array}{c}\mathbf{1 1} \\
\mathbf{0}\end{array}$ & I \\
\hline Security & 12 & 15 & 22 & 19 & $\mathbf{6 8}$ & VIII \\
\hline High Charges & 16 & 22 & 34 & 30 & $\begin{array}{c}\mathbf{1 0} \\
\mathbf{2}\end{array}$ & III \\
\hline Unreliability & 15 & 21 & 28 & 31 & $\mathbf{9 5}$ & VI \\
\hline Inaccessibility & 14 & 13 & 12 & 11 & $\mathbf{5 0}$ & IX \\
\hline No Awareness & 13 & 20 & 33 & 32 & $\mathbf{9 8}$ & V \\
\hline $\begin{array}{l}\text { Operation methods } \\
\text { Not Users Friendly }\end{array}$ & 16 & 23 & 36 & 29 & $\begin{array}{c}\mathbf{1 0} \\
\mathbf{4}\end{array}$ & II \\
\hline $\begin{array}{l}\text { Non-Updating } \\
\text { Transactions }\end{array}$ & 15 & 23 & 32 & 30 & $\begin{array}{c}\mathbf{1 0} \\
\mathbf{0}\end{array}$ & IV \\
\hline
\end{tabular}

It is observed from the table 6 that the majority of all the category of the respondents are faced the problem "Handset Operability". Hence first rank is gained by this problem. The second rank gained by the issue "Method of operation". "Highest Charges" is another problem respondent by 102 respondents. It is placed third rank. Fourth rank goes to "Non-updating the transactions" immediately in to the server. Fifth rank gained by "No awareness" about the operation method of mobile banking. Sixth place goes to "Unreliability". Other problems scored minimized responses from the respondents and scored following ranks.

\subsection{LEVEL OF SATISFACTION SERVICES \\ AGAINST}

Satisfaction is motivating users and increase the usage level. The service providers must concentrate in the customer satisfaction. It decides through various factors like increasing turnover, increase of mobile banking transactions, reduction of issues, depends on the socio-economic factors, adopting new technology and implementation methods. The researcher made an attempt to analyse the satisfaction level regarding M Banking service and result is presented in Table no 7.

\section{TABLE NO 7. LEVEL OF SATISFACTION AGAINST SERVICES}

\begin{tabular}{|c|c|c|c|c|c|c|c|c|}
\hline \multirow{2}{*}{ Details } & \multicolumn{2}{|c|}{ Age 18} & \multicolumn{2}{|c|}{ Age 19} & \multicolumn{2}{|c|}{ Age 20} & \multicolumn{2}{|c|}{ Age $>20$} \\
\hline & res & per & res & per & res & per & res & per \\
\hline Satisfy & 10 & 30 & 18 & 54 & 26 & 78 & 16 & 48 \\
\hline Neutral & 3 & 6 & 3 & 6 & 8 & 16 & 12 & 24 \\
\hline $\begin{array}{l}\text { Not } \\
\text { Satisfy }\end{array}$ & 4 & 4 & 2 & 2 & 3 & 3 & 5 & 5 \\
\hline Total & 17 & 40 & 23 & 62 & 37 & 97 & 33 & 77 \\
\hline Result & \multicolumn{2}{|c|}{$40 / 51 \times 100$} & \multicolumn{2}{|c|}{$62 / 69 \times 100$} & \multicolumn{2}{|c|}{$97 / 111 \times 100$} & $77 / 99 \times 100$ & $\begin{array}{l}100 \\
\%\end{array}$ \\
\hline
\end{tabular}


Table No.7 shows that the respondent's opinion towards mobile banking services. The satisfaction score secured by the 18 years age category 78.43 percent, 19 years age category 89.86 percent, 20 years are category 87.39 percent and above 20 years age category scored 77.78 percent respondents and overall score is 83.64 percent. They opined that they are satisfied with mobile banking services. Very few respondents are not satisfied with that services.

\subsection{SERVICE CHARGES}

Services are provided by the banker with highest investment in infrastructure development. The amount is charged for fund transfer, payments, card transactions, transfer from one to another account and banker, monthly maintenance charges, transaction charges varied based on time and amount and cash handling charges. The charges are categorized like Less than Rs.15, charges between Rs. 15 and Rs. 25 and more than Rs. 25. It has been analysed and the result is presented table 8 .

TABLE NO 8. SERVICE CHARGES

\begin{tabular}{|l|c|c|}
\hline \multicolumn{1}{|c|}{ Particulars } & Res & Per \\
\hline Less Than Rs.15 & 95 & 86.37 \\
\hline Rs.15-25 & 6 & 5.45 \\
\hline More Than Rs.25 & 9 & 8.18 \\
\hline Total & $\mathbf{1 1 0}$ & $\mathbf{1 0 0}$ \\
\hline
\end{tabular}

Table No.8 states that the among the sample respondents 86.37 paid amount less than Rs. 15 for their mobile banking transactions. 8.18 percent of respondents contributed more than Rs. 15 for their banking transactions. 5.45 percent respondents are spending between Rs. 15 to Rs. 25 for transaction.

\subsection{NUMBER OF COMPLAINTS REGISTERED}

Customers are facing end number of problems while using mobile banking, net banking and plastic card transaction. The researcher analyzed that the respondents are file a complaint against their problems faced in mobile banking and the result is presented in table 9.

TABLE NO 9. NO OF COMPLAINT REGISTERED

\begin{tabular}{|l|c|c|c|c|}
\hline \multicolumn{1}{|c|}{ Particulars } & Yes & Per & No & Per \\
\hline 18 Years & 10 & 13.15 & 7 & 20.59 \\
\hline 19 Years & 15 & 19.74 & 8 & 23.53 \\
\hline 20 Years & 28 & 36.84 & 9 & 26.47 \\
\hline More than 20 years & 23 & 30.26 & 10 & 29.41 \\
\hline Total & $\mathbf{7 6}$ & $\mathbf{1 0 0}$ & $\mathbf{3 4}$ & $\mathbf{1 0 0}$ \\
\hline
\end{tabular}

It is learnt from the above table 9 that 36.84 percent in 20 years category, 30.26 percent in more than 20 years category, 19.74 percent in 19 years category and 13.15 percent under 18 years category respondents made complaint to the banker against their problems. 20 percent to 25 percent of the respondents not filed complaint against their problem.

\subsection{ACTION TAKEN AGAINST COMPLAINT}

The researcher analysed the remedial action taken against the complaints filed by the respondents. The actions may classify like immediate solvency, giving suggestions and problems not yet solved. It helps to improve the services and motivate to avail mobile banking services. The result is presented in table no 10.

\section{Table No 10. Remedial Action Against Complaint}

\begin{tabular}{|l|c|c|c|c|c|c|}
\hline \multirow{2}{*}{ Particulars } & \multicolumn{2}{|c|}{ Immediately solved } & \multicolumn{2}{c|}{ Given Suggestion } & \multicolumn{2}{c|}{ Not Solved } \\
\cline { 2 - 8 } & Res & Per & Res & Per & Res & Per \\
\hline 18 Years & 11 & 18.03 & 3 & 11.54 & 3 & 13.04 \\
\hline 19 Years & 12 & 19.67 & 6 & 23.07 & 5 & 21.74 \\
\hline 20 Years & 18 & 29.51 & 10 & 38.46 & 9 & 39.13 \\
\hline More than 20 years & 20 & 32.79 & 7 & 26.92 & 6 & 26.09 \\
\hline Total & $\mathbf{6 1}$ & $\mathbf{1 0 0}$ & $\mathbf{2 6}$ & $\mathbf{1 0 0}$ & $\mathbf{2 3}$ & $\mathbf{1 0 0}$ \\
\hline
\end{tabular}

It is inferred from the above table 10, majority of the respondent's complaints are immediately solved by the banker. 26 respondent complaints are rectified and the banker given suggestion to avoid problems in their bank transactions. 23 respondent problem is not able to solved.

\subsection{ATTITUDE ABOUT FREE SERVICE CHARGE}

Attitude measurement is important in marketing because of the central role it plays in developing segmentation, evaluating the effectiveness of advertising, predicting, and product acceptances and facilitating the development of marketing programmes. The three components of an attitude are a) cognitive - relating to beliefs b) affective - relating to feelings and c) behavioral - relating to action tendency. The most common way of assessing consumer attitudes is through the administration of a questionnaire containing attitude scales. While a great many attitude-scaling procedures have been available, the Likert scale, otherwise called as summated scale, is by far the most popular form of attitude scaling because it is easy for researchers to prepare and uncomplicated for consumers to respond. The Likert's scale has several advantages over other indirect scaling techniques. It is reasonably easy to construct and administer because of the simplicity of the instructions. "The evidence to date indicates that the Likert scale is more reliable than the Thurstone method". Hence the researcher has adopted the Likert's scaling technique for analyzing the attitudes of the consumers in this study in the M-Banking the service charges and it plays a major role. Charges are differed from each and every transaction which is carried out by the customer through mobile banking. The result is given in table no 11 .

Table No. 11 Attitude About Free Service Charge

\begin{tabular}{|l|c|c|}
\hline \multicolumn{1}{|c|}{ Particulars } & Res & Score \\
\hline Strongly Agree & 1 & 5 \\
\hline Agree & 5 & 10 \\
\hline NAND & 2 & 6 \\
\hline Disagree & 42 & 84 \\
\hline Strongly Disagree & 60 & 60 \\
\hline Total & $\mathbf{5 5 0}$ & $\mathbf{1 6 5}$ \\
\hline Result & $\mathbf{1 6 5 / 5 5 0} * \mathbf{1 0 0}=\mathbf{3 0}$ \\
\hline
\end{tabular}


The above table 11 shows that the respondent's opinion towards free service charge. Majority of respondents are strongly disagreed that the mobile banking service charges are not free. The satisfaction score given by the respondent's 30 percent.

\subsection{EXTRACTION OF FACTORS UNDERLYING USERS ATTITUDE TOWARDS MOBILE BANKING}

The rotated matrix of factor co-efficient or factor loadings given in the Table 12 summarizes the results of factor analysis for using mobile banking services. The KaiserMeyer-Olkin (KMO) and Bartlett's coefficient is 0.440. The analysis has given five factor solutions (F1 to F4) to find out the influence of groups of inter-correlated variables on user's attitude called factors. This is evident from the Table 13. The results reveal that all the factors taken together have accounted for 69.20 percent of the total variations. Further the results are reliable as the communality values have been high.

TABLE NO. 12 OPINION TOWARDS MOBILE BANKING

\begin{tabular}{|c|l|c|}
\hline \multicolumn{2}{|c|}{ Kaiser-Meyer-Olkin Measure of Sampling Adequacy. } & $\mathbf{. 4 4 0}$ \\
\hline \multirow{2}{*}{$\begin{array}{c}\text { Bartlett's Test of } \\
\text { Sphericity }\end{array}$} & Approx. Chi-Square & 84.558 \\
\cline { 2 - 3 } & df & 45 \\
\cline { 2 - 3 } & Sig. & .000 \\
\hline
\end{tabular}

The first factor has explained 26.35 per cent of the total variations and encompasses the following variables "System configurations", " $24 \times 7$ services", "Mobile banking system more helpful" and "No transaction limit" In these factor all the variables have been positively loaded and the infrastructure of mobile banking services has a high positive correlation with the first four variables with the factor. It implies that all the variables in the factor have positive influence on the effect of infrastructure described by users. The factor has been termed as 'Infrastructural Factor'.

\section{TABLE NO. 13 FACTORS EXTRACTION TOWARDS} MOBILE BANKING OPINION

\begin{tabular}{|c|l|c|c|c|c|c|}
\hline Sl.No & \multicolumn{1}{|c|}{ Variables } & F1 & F2 & F3 & F4 & Com \\
\hline 1 & System Configure & $\mathbf{. 8 6}$ & .15 & .04 & .25 & $\mathbf{. 8 3}$ \\
\hline 2 & $24 * 7$ Services & $\mathbf{. 6 7}$ & .26 & .02 & .26 & $\mathbf{. 6 0}$ \\
\hline 3 & It is more helpful & $\mathbf{. 6 5}$ & .42 & .28 & .25 & $\mathbf{. 7 5}$ \\
\hline 4 & No transaction limit & $\mathbf{. 6 0}$ & .00 & .09 & .52 & $\mathbf{. 6 4}$ \\
\hline 5 & No service charges & .29 & $\mathbf{. 8 0}$ & .26 & .08 & $\mathbf{. 8 1}$ \\
\hline 6 & Easy access & .18 & $\mathbf{. 6 3}$ & .18 & .26 & $\mathbf{. 5 4}$ \\
\hline 7 & Moderate Charges & .15 & $\mathbf{. 5 8}$ & .53 & .50 & $\mathbf{. 9 1}$ \\
\hline 8 & Safety & .05 & .26 & $\mathbf{. 6 7}$ & .20 & $\mathbf{. 5 7}$ \\
\hline 9 & New technology & .48 & .17 & $\mathbf{. 5 5}$ & .18 & $\mathbf{. 6 1}$ \\
\hline 10 & Time consuming & .49 & .24 & .13 & $\mathbf{. 5 4}$ & $\mathbf{. 6 2}$ \\
\hline \multicolumn{2}{|l|}{ Percentage of variance } & $\mathbf{2 6 . 3}$ & $\mathbf{1 8 . 3}$ & $\mathbf{1 2 . 6}$ & $\mathbf{1 1 . 8}$ & $\mathbf{6 9 . 2}$ \\
\hline \multicolumn{2}{|l}{ Eigen value } & $\mathbf{4 . 3 3}$ & $\mathbf{2 . 7 7}$ & $\mathbf{1 . 6 3}$ & $\mathbf{1 . 3 8}$ & \\
\hline
\end{tabular}

The second factor has been represented by the variable such as "No service charges", "Easy access" and "Moderate Charges". This factor has explained with 18.36 per cent of the total variations. The variable is positively loaded and so it means that this factor has a positive influence on charges. It also shows that the charges have been influenced mainly consider the usage of mobile banking services. That variable is related to carry and hence the factor can be named as 'Services Charges factor'.

The third factor "Safety" and "Adoption of new technology". It has accounted for 12.67 per cent of the total variations. The loadings in this factor has been heavily loaded positively. As these variables deal with safety, so it may be termed as 'Security Factor'.

The fourth factor "Time consuming". It has accounted for 11.82 per cent of the total variations. The loadings in this factor has been heavily loaded positively. As this variable deal with duration. so, it may be termed as 'Time Factor'.

\section{FINDINGS}

\$15.45 percent respondents are under 18 years category, 20.9 percent respondents are falls on 19 years category, 33.6 percent respondents are coming under the 20 years category and 30 percent respondents are above 20 years category.

\$51 percent comes under Male and 49 percent of peoples falls on the female category. 61.8 percent of students are completed UG and 38.2 percent of the respondents completed PG degree.

\#Majority of the respondents doing their banking transactions through public sector banks. 20 years age category of respondents highly using public sectors bank mobile services.

\$30 percent of students are using the M-Banking services a year. 26.36 percent of students are using $M$ banking service between 1 year to 3 years and 43.64 percent of students are using more than 3 years.

\# Majority of the respondents change their mobile banking password through only mobile. This feature is secured first rank. The second rank secured by Transaction history. Third place goes to Viewing account balance.

\$ Majority of all the category of the respondents are faced the problem "Handset Operability". Hence first rank is gained by this problem. The second rank gained by the issue "Method of operation". "Highest Charges" is another problem respondent by 102 respondents. It is placed third rank. Fourth rank goes to "Non-updating the transactions" immediately in to the server.

\#The satisfaction score secured by the 18 years age category 78.43 percent, 19 years age category 89.86 percent, 20 years are category 87.39 percent and above 20 years age category scored 77.78 percent respondents and overall score is 83.64 percent.

\$86.37 paid amount less than Rs. 15 for their mobile banking transactions. 8.18 percent of respondents contributed more than Rs. 15 for their banking 
transactions. 5.45 percent respondents are spending between Rs. 15 to Rs. 25 for transaction.

$\$ 36.84$ percent in 20 years category, 30.26 percent in more than 20 years category, 19.74 percent in 19 years category and 13.15 percent under 18 years category respondents made complaint to the banker against their problems.

\$ Majority of the respondent's complaints are immediately solved by the banker. 26 respondent complaints are rectified and the banker given suggestion to avoid problems in their bank transactions. 23 respondent problem is not able to solved.

\$ Majority of respondents are strongly disagreed that the mobile banking service charges are not free. The satisfaction score given by the respondent's 30 percent.

\$The first factor has explained 26.35 per cent of the total variations and encompasses the following variables "System configurations", " $24 \times 7$ services", "Mobile banking system more helpful" and "No transaction limit" In these factor all the variables have been positively loaded and the infrastructure of mobile banking services has a high positive correlation with the first four variables with the factor. It implies that all the variables in the factor have positive influence on the effect of infrastructure described by users. The factor has been termed as 'Infrastructural Factor'. The second factor has been represented by the variable such as "No service charges", "Easy access" and "Moderate Charges". This factor has explained with 18.36 per cent of the total variations. The variable is positively loaded and so it means that this factor has a positive influence on charges. It also shows that the charges have been influenced mainly consider the usage of mobile banking services. That variable is related to carry and hence the factor can be named as 'Charges factor'.

\section{CONCLUSION}

Mobile banking is big platform of new technology which promotes banking functions in India through mobile technology and also helps increasing their customers. Now a days, everyone has smartphone or tablet but there is also need to create awareness about the mobile banking services which is very secure and safe without any efforts. Finally, the researcher conclude that the $\mathrm{M}$ banking is giving more additional features to the customers at the same time, charges are heavy, transactions must be in secured and safety nature and it is not user friendly for the illiterate. College students are accessing mobile services in various aspects in their life such as social media, banking services and life is in their pocket.

\section{REFERENCES}

[1] Manav Aggarwal, A study on importance of Mobile Banking, Indian Journal of Applied research, Vol. 4, Issue no.5
[2] Mobile Banking in India: Issues \&Challenges. International Journal of Emerging Technology and Advanced Engineering, Vol. 3 Issue no. 6

[3] M-Banking and M-Payments Services in the Developing World: Complements or Substitutes for Trust and Social Capital? International Communication Association

[4] Mobile Banking Adoption and Benefits towards Customers Service. International Journal on Advanced Computer Theory and Engineering, Vol. 2, Issue no. 1

[5] R. Tiwari and S. Buse, The Mobile Commerce Prospects: A Strategic Analysis of Opportunities in the Banking Sector. Hamburg University Press, Hamburg, 2007.

[6] A. Ashta, "Evolution of Mobile Banking Regulations," Journal of Internet Banking and Commerce, vol. 10(7), pp. 12-16, 2003.

[7] Y. Wang, Y. Wang, H. Lin and T. Tang, "Determinants of user acceptance of internet banking: an empirical study," International Journal of Bank Marketing, vol. 14(5), pp. 501519,2010

[8] A.A. Al-Ashban and M.A. Burney, "Consumer adoption of tele-banking technology: the case of Saudi Arabia," International Journal of Bank Marketing, vol. 19(5), pp. 191200, 2001.

[9] S. Dasgupta, R. Paul and S. Fuloria, "Factors affecting behavioral intentions towards mobile banking usage: Empirical evidence from India," Romanian Journal of Marketing, vol. 3(1), pp. 6-28, 2011.

[10] M. AL-Majali and N.K. Mat, "Modeling the antecedents of internet banking service adoption (IBSA) in Jordan: A Structural Equation Modeling (SEM) approach," Journal of Internet Banking and Commerce, vol. 16(1), pp. $1-15,2011$.

[11] A. Patel, M-Banking and M-Payments: The Next Frontier. Delhi: Deloitte, 2013.

[12] T. Bhatti, "Exploring Factors Influencing the Adoption of Mobile Commerce," Journal of Internet Banking and Commerce, vol. 12(1), pp. 1-13, 2007.

[13] L. Bradley and K. Steward, "A Delphi study of the drivers and inhibitors of Internet banking," International Journal of Bank Marketing, vol. 20(6), pp. 250-260, 2002.

[14] N. Singh and N. Sinha, "A Study on Mobile Banking and its Impact on Customer's Banking Transactions: A Comparative Analysis of Public and Private Sector Banks in India," FIIB Business Review, vol. 5(2), pp. 74-87, 2016.

[15] P.B. Sharma and P. Singh, "Issues \& Challenges in Mobile Banking in India: A Customers' Perspective," Research Journal of Finance and Accounting, vol. 2(2), pp. 112-120, 2011. 